\title{
Therapeutic Assessment as an Interventional Model of Psychological Evaluation: Case Study
}

\author{
Scarlett Borges Fernandes ${ }^{1}$ \\ Rebeca de Moura Targino ${ }^{2}$ \\ Fernanda da Fonseca Giasson ${ }^{3}$ \\ Lucila Moraes Cardoso ${ }^{3}$ \\ ${ }^{1}$ Universidade São Francisco, Campinas, São Paulo, Brasil \\ ${ }^{2}$ Universidade Federal do Ceará, Fortaleza, Ceará, Brasil \\ ${ }^{3}$ Universidade Estadual do Ceará, Fortaleza, Ceará, Brasil
}

\begin{abstract}
Therapeutic Assessment is a model of psychological evaluation that adopts a collaborative approach and a semi-structured systematization to the extent that it has well-defined steps. Considering its intervention nature, Therapeutic Assessment seeks to bring about positive changes in the lives of clients and/or people close to them. The present study aimed to evaluate how the Therapeutic Assessment process presented therapeutic consequences, using the case study as a research method. The description of the results was based on the assistance of a client using the Therapeutic Assessment model. The findings corroborate the hypotheses related to the therapeutic benefits of the Therapeutic Assessment, providing the clients with increased self-knowledge and self-reflection and changes in the way they deal with difficult situations. We conclude that more research on Therapeutic Assessment should be developed to verify other possible benefits of the model.

Keywords: psychological evaluation, psychotherapy, interventive assessment.
\end{abstract}

\section{Avaliação Terapêutica como um Modelo Interventivo de Avaliação Psicológica: Estudo de Caso}

\section{Resumo}

A Avaliação Terapêutica é um modelo de avaliação psicológica que adota uma abordagem colaborativa e uma sistematização semiestruturada na medida em que possui etapas bem definidas. Considerando seu caráter interventivo, a Avaliação Terapêutica busca proporcionar mudanças positivas na vida dos clientes e/ou de pessoas próximas a ele. O presente estudo objetivou avaliar de que maneira o processo de Avaliação Terapêutica apresentou consequências terapêuticas, utilizando-se o estudo de caso como método de investigação. A descrição dos resultados orientou-se por meio do atendimento de uma cliente utilizando o modelo de Avaliação Terapêutica. Os achados corroboram com as hipóteses relacionadas aos benefícios terapêuticos da Avaliação Terapêutica, possibilitando à cliente aumento do autoconhecimento e da autorreflexão e mudanças na sua maneira de lidar com situações difíceis. Conclui-se que mais pesquisas sobre Avaliação Terapêutica devem ser desenvolvidas para se verificar outros possíveis benefícios do modelo.

Palavras-chave: avaliação psicológica, psicoterapia, avaliação interventiva.

\section{La Evaluación Terapéutica como modelo intervencionista de Evaluación Psicológica: estudio de caso}

La Evaluación Terapéutica es un modelo de evaluación psicológica que adopta un enfoque colaborativo y una sistematización semiestructura, visto que cuenta con etapas bien definidas. Considerando su carácter intervencionista, la Evaluación Terapéutica busca proporcionar cambios positivos en la vida de los clientes y/o de personas cercanas a él. El presente estudio objetivó evaluar de qué manera el proceso de Evaluación Terapéutica presenta consecuencias terapéuticas, utilizando el estudio de caso como método de investigación. La descripción de los resultados se orientó por la atención de una cliente, utilizando el modelo de Evaluación Terapéutica. Los hallazgos corroboran con las hipótesis relacionadas con los beneficios terapéuticos de la Evaluación Terapéutica, posibilitando al cliente el aumento del autoconocimiento, de la autorreflexión y cambios en su manera de lidiar con situaciones difíciles. Se concluye que se deben desarrollar más investigaciones sobre Evaluación Terapéutica para verificar otros posibles beneficios del modelo.

Palabras clave: evaluación psicológica, psicoterapia, evaluación intervencionista.

\section{Introduction}

Therapeutic Assessment (TA) is a model of interventional psychological assessment that adopts a collaborative approach and has a semi-structured systematization (Durosini, Tarocchi \& Aschieri, 2017; Fantini, 2016; Finn, 2017; Saeger, Bartak, Eder \& Hamphus, 2016; Villemor-Amaral \& Resende, 2018).
According to Villemor-Amaral (2016), TA differs from other traditional models of evaluation due to its originality, theoretical neutrality, and semi-structured organization.

In the development of TA, Finn was strongly influenced by Connie Fischer, who developed a humanscientific philosophy based on the phenomenological framework, which represents an essential aspect for the 
therapeutic impact of the evaluation. This prerogative of collaboration guides the assessment process from the involvement of the client in the step that determines the questions that will be worked on, to the step when the client and assessor meet after the conclusion of the assessment, to discuss issues that arose and evaluate possible changes produced during and after the process (Finn, 2017; Saeger et al., 2016).

Finn $(2015,2017)$ systematized the TA process in 6 steps, which were structured using practical checks. The first step concerns the initial sessions, in which the client is guided to formulate questions about him- or herself that should lead the evaluation process. Consistent with the humanist premises related to the client's centrality, the entire TA process will take these questions as a basis, considering them at all times and not exceeding the limits imposed by the client regarding what he or she would like to evaluate. Additionally, Finn (2017) emphasizes that the formulation of the questions must be conducted in such a way that the client is actively positioned in what he or she intends to assess, allowing the assessment to be a process of recognition also of the mechanisms of change that are potentially present in the client. After exploring the content related to the guiding question, it is suggested that the psychologist asks the client about what would be the most difficult answers to the questions asked. It is a strategy to track the fears, worries, and the level of knowledge that the client has about him- or herself.

The second step refers to the standardized test sessions, in which the assessor must administer psychological assessment instruments in a manner consistent with the aspects that the client would like to evaluate, associated with the questions elaborated by him or her in the previous stage. Finn (2017) highlights the importance of always explaining to the client how this test is related to the aspects to be evaluated, stating that such sessions should start with the administration of the instrument that is relevant to the evaluation of the client's central question.

Tests should be administered according to the standardized guidelines of each instrument, since these sessions are very similar to those in traditional assessments (Finn, 2015, 2017). Regarding the functionality of psychological tests in TA, they are used to help people better understand themselves and find solutions to their problems. Considering this objective, the extended inquiry stands out, a process after the administration of the tools, which aims to explore responses and tests' results. This step can be conducted by different techniques, which can be configured as simple questions directed to the client about their thoughts or reactions when answering a particular instrument (Aschieri \& Smith, 2012; Hinrichs, 2015).

The third step concerns the intervention sessions, in which the assessor aims to bring the problematic behaviors of the client to the service room, thereby seeking to identify them, analyze them, and elaborate possible changes (Fantini, 2016; Finn, 2017). Fantini (2016) points out alternatives used to promote the practical experience that the interventional sessions propose, such as the use of psychodramatic techniques, games, or test stimuli as techniques. These sessions are prepared based on elements derived from the conflicts addressed by the client, their defenses, and their issues, which can be discussed and, to the extent that the client understands them, generalized for his or her life.

The fourth step refers to the summary and discussion sessions, in which the assessor must elaborate and discuss, together with the client, the main points that emerged during the evaluation process (Durosini, et al., 2017). In this step, the client is informed that the assessor will prepare and send a letter with a summary of his or her impressions about the points he or she considered most significant in the process (Durosini, et al., 2017; Finn, 2017). In addition, the client is invited to answer an Assessment Questionnaire, which will be sent with the letter.

The Assessment Questionnaire is a resource produced by Finn and collaborators that aims to evaluate, from the client's perspective, the TA process (Finn, 2017). The instrument consists of 48 statements that are subdivided into 4 factors, namely new self-awareness or understanding, accurate positive mirroring, positive relationship with the examiner, and negative feelings about the assessment. The questionnaire uses the 5-point Likert scale model, ranging from strongly disagree to strongly agree.

The fifth step is to send the letter and the Evaluation Questionnaire. The sixth and final step is called follow-up and is characterized by the realization of sessions some time after the evaluation process has been completed (usually 4-6 weeks), and can function, according to Finn (2017), as "reinforcement sessions" to strengthen the beneficial aspects of TA.

Peters et al. (2008) show that the Therapeutic Assessment process is successful when the client feels understood, evaluated, and respected by the professional and realizes that the answers to the initial questions produced some significant change for the 
better. Case studies on TA with adults have been developed in several countries (Aschieri \& Smith, 2012; Chudzik, 2015; Durosini, et al., 2017; Fantini, 2016; Finn, 2017; Hinrichs, 2015) and highlighted the benefits that the evaluation process provided to customers.

In Brazil, the literature on TA is still limited, with no publications on experimental cases in the model to date (Villemor-Amaral, 2016; Villemor-Amaral \& Resende, 2018; Scaduto, Cardoso \& Heck, 2019). Thus, the present study aimed to assess how the TA process has therapeutic consequences for the client.

\section{Method}

\section{Participant}

The study was conducted with a client who was awaiting psychological treatment at the Applied Psychology Service (APS) of a public university's Psychology course. Tulipa (fictitious name) is a 53-yearold single woman, retired teacher, who lives with her mother and daughter.

\section{Instruments}

The instruments described herein are divided according to the period in which they were administered, during the screening or the evaluation process. In the screening period, 4 fundamental sources and 3 additional sources of psychological assessment were used, as defined in resolution CFP No. 009/2018. Regarding the 4 psychological tests used during the TA process, the favorable character for use issued by the Psychological Test Evaluation System (Satepsi) is emphasized, in addition to the fact that the instruments were administered according to the standard guidelines contained in the technical manuals.

\section{Screening Instruments}

The Self-Reporting Questionnaire (SRQ) is a self-administered questionnaire designed to detect symptoms at the level of suspicion of some mental disorder, and although it does not discriminate against a specific diagnosis, it does allow the investigation of non-psychotic morbidity. In Brazil, validity evidence studies were developed by Santos, Araújo, Pinho, and Silva (2011), and satisfactory evidence of validity and reliability were found for the use of the questionnaire.

The Rosemberg Self-Esteem Scale (RSES) is intended to classify the level of self-esteem, consisting of 10 items answered using a 4-point Likert scale ranging from totally agree, agree, disagree, and strongly disagree. In Brazil, the study developed by Hutz and Zanon (2011) showed satisfactory evidence regarding the psychometric properties of the RSES.

The Magical Ideation Scale (MIS) is designed to evaluate magical thoughts using 30 items with the possibility of a dichotomous response of the true or false type. The MIS was translated and adapted in Brazil by Vieira, Villemor-Amaral, and Pianowski (2017), who conducted studies of evidence of validity using the discriminative sensitivity of the instrument for groups of patients and non-patients, finding consistent results.

The Beck Scales aims to signal a measure of intensity of depression, symptoms of anxiety, hopelessness, and suicidal ideation. The Brazilian version was translated and adapted by Cunha (2001), and the battery of tests includes the Depression Inventory (BDI), the Anxiety Inventory (BAI), the Despair Scale (BHS), and the Scale for Suicidal Ideation (SSI).

\section{Instruments used during the evaluation}

The Personality Factor Battery (BFP) is used to assess personality using the Big Five Factors (BFF) model, which includes the dimensions Neuroticism, Extroversion, Socialization, Realization, and Openness. It is a self-administered instrument, consisting of 126 items, and administration is recommended for people who have at least completed Elementary School. Regarding the psychometric qualities described in the BFP manual, 9 validity evidence studies were presented, 4 focused on the context of career guidance, 1 for intelligence assessment, and 4 for personality assessment (Nunes, Hutz, \& Nunes, 2014). (Nunes, Hutz, \& Nunes, 2014).

The Family Support Perception Inventory (IPSF) aims to assess the perception about the family dynamics in which the appraiser is inserted, considering, for that, the affectivity, autonomy, and adaptation among the members. The instrument is intended for people aged 11 to 57 years and can be administered individually or collectively, stipulating a maximum time of 20 minutes for its administration. The IPSF consists of 42 statements related to family situations, and it is up to the client to identify the frequency with which each of them occurs in their family context. Eleven validity evidence studies were developed, 2 characterized as construct validity, and 9 based on relationships with other variables. Regarding the IPSF accuracy, all the factors presented values greater than 0.70 using Cronbach's alpha, and were considered satisfactory (Baptista, 2009). 
The Rorschach Method aims to assess personality structure from cognitive, affective, and interpersonal aspects. The test consists of 10 slides that exhibit ink blots with a not very defined contour and variable texture, with perfect symmetry in relation to the vertical axis. The instrument must be administered individually, consisting of 2 standardized steps. The test can be used for individuals of different age groups, noting that, in the present study, its administration was performed according to the Comprehensive System (Exner, 1999).

The Thematic Apperception Test (TAT) is based on the principle that different individuals when submitted to the same life situation, experience it in different ways, consistent with their corresponding personal perspectives. TAT was developed to assess personality by identifying the relationship between the individual's needs and the demands of the environment (Murray, 2005). With regard to administration, the instrument's target population is people who do not have communication difficulties, and individual application should be conducted. Its material consists of a set of 31 boards containing reproductions of dramatic situations, with imprecise contours, diffuse printing, and an inexplicable theme.

\section{Procedures}

The present study is a graft from a research project presented to the Research Ethics Committee and approved in May 2017, under opinion No. 2.043.750. After approval of the project, Tulipa, who was awaiting psychological treatment at the Applied Psychology Service (APS) of a public university, was contacted. At the first meeting, the client was invited to voluntarily participate in the research and signed a Free and Informed Consent Form (ICF). Initially, the instruments related to the screening step were administered. Then, the TA sessions were scheduled, which lasted from 60 to 90 minutes and were conducted in an APS room, by a psychologist who was a master's student at that University. During the process, we sought to meet the recommendations described by Finn (2017) concerning the importance of using recording material during the TA process, opting to record the sessions, with the client's authorization.

\section{Results}

\section{Step 1 - Initial Sessions}

Three initial sessions were developed, in which Tulipa presented complaints associated with selfimage, feelings of fear/concern, and the dynamics of her daughter's relationship with her daughter's father. Regarding Tulipa's perception of herself, the client brought her shyness as an emerging aspect, discussing issues inherent to the difficulty in sharing feelings and opinions, feeling overwhelmed by not being able to share them. The discussion regarding this complaint culminated in the elaboration of the first guiding question, namely, "How can I, in the face of such a big problem, still not feel the need to share?"

Later, Tulipa described an exacerbated concern about the possibility of something bad happening, which, according to the client, became excessive after her brother's death in a work accident. Fear was also present concerning health and Tulipa identified an increase in her concern after being submitted to cancer treatment, in which she achieved a cure. Faced with this theme, the client asked the question "Why, in some situations, am I so afraid that something bad will happen?"

The client also described the distant relationship between her daughter and her daughter's father, pondering her desire to be able to have done something different to improve this relationship. Given this, Tulipa initially asked the question "How could I have helped the relationship between my daughter and her father?" In the second session, Tulipa was encouraged to re-elaborate this question, however, reflecting on the importance of the question for her process at that time, the client chose to exclude it, highlighting that it was something that belonged to the past.

In the 2 subsequent sessions, the themes brought up by Tulipa were discussed and deepened, seeking, in a collaborative way, to understand which aspects intertwined in the initial demands could be the focus of the evaluation. Also in these sessions, the psychologist investigated, with the client, which would be the most difficult answers to the guiding questions she created, being punctuated by Tulipa that, concerning the first question, she would have to change her way of being, and regarding the second, the diagnosis of some abnormality or the discovery that it is pessimistic.

\section{Step 2 - Standardized Tests Sessions}

A total of 3 sessions were held for administering psychological tests. The BFP and IPSF were administered in the first session, the Rorschach test in the subsequent session, and finally, the TAT.

\section{Summary of Administered Tests}

The data obtained through the BFP suggested that Tulipa tends to have low self-esteem, worrying 
about the possibility of important people walking away due to mistakes made, and she may have attitudes that do not represent her will to summarily please the others. Information related to the IPSF demonstrated that Tulipa presents a perception of family support associated, initially, with a low expression of affection among family members, which is related to aspects of communication, interaction, respect, and problem-solving skills.

The results of the Rorschach test showed a tendency for the client to behave cautiously in exposure situations, trying to avoid them. In complex, emergency or crisis circumstances, she usually remains calm and balanced, having a good ability to tolerate situations of overload situations with signs that, even in uncertain situations, she does not usually ask for help or feels the need to change her way of thinking. Regarding TAT, Tulipa demonstrated involvement with the task, presented an organized speech and adequate use of language, indicating a preserved contact with reality, satisfactory intellectual level, and efficient control of anxiety.

\section{$\underline{\text { Step } 3 \text { - Intervention Sessions }}$}

Four sessions were developed, being the first an analysis of the information obtained from the administration of the tests and the establishment of associations between these and the guiding questions elaborated by Tulipa during the initial sessions. The main themes discussed were related to the difficulties in dealing with the new, the excessive concern with opinions and desires of others, the apparent self-control, and the repression of emotions.

In the second session, Tulipa stated that the previous session had been "the best so far." The psychologist proposed that the client responded to the Zulliger test, seeking to work on the client's difficulty in expressing what she feels in adverse situations and the tendency to behave in a certain way in favor of someone else's wishes. Although Tulipa showed some dissatisfaction with the activity, she eventually accepted the task. In the end, the psychologist and the client identified and analyzed the problematic behavior, conducting a reflexive process regarding this dynamic of functioning.

In the third intervention session, Tulipa reported that she had reflected on the previous session, which had taken place 15 days earlier, and concluded that she often could not express her feelings for fear of hurting others. In this regard, she justified her absence in the previous session by reporting that she "was not in the mood," showing openness to verbalize her feelings honestly. The professional compared Tulipa's reaction to that of the last session, and in this regard, the client said she felt good about being able to talk about her feelings. Also in this session, the client's concerns about the well-being of others were discussed. For this, the slide 16 of the TAT test was used, which is completely blank, and the psychologist read the story created by Tulipa about her childhood. The client was moved to hear the story and recalled some moments when she was a child.

Later, the psychologist worked, together with the client, on the difficulty of dealing with losses. In this theme, the assessor used the boards 3,12, 13, 15, and 18 of the TAT test and read the stories prepared by the client. Tulipa was surprised to identify the content of death in her stories. The client acknowledged having difficulties in talking about the subject and was moved to share that, possibly, she had never allowed herself to mourn her brother's death.

In the fourth and last intervention session, the psychologist used as a tool the exposure of 3 images that were associated with situations experienced by the client. The images referred to Tulipa's passive attitude towards her mother's wishes and the search for simplistic solutions for complex circumstances. During the meeting, the psychologist invited her to choose one illustration at a time and, at the same time, narrated stories of problem situations conducted by people who are close to the client. In the end, she asked Tulipa to come up with possible solutions to problematic situations. Regarding the client's attitude, it is noteworthy that, in this session, she was able to ponder and find solutions when the protagonist of the stories was someone else.

The psychologist then presented Tulipa with 4 clippings from previous sessions that were related to her simplistic way of giving answers. The assessor pointed out that the client was able to analyze and reflect, in a complex way, about solutions to other people's problematic situations, when compared to situations in which she was the protagonist. Tulipa was surprised to identify such a stance and agreed that she tends to seek less complex solutions to her problems. The psychologist and client reflected on other possible behaviors in the face of these situations, concluding that, many times, Tulipa will not be able to deviate from all difficult situations, and when this happens, it will be necessary to develop complex solutions. 
Step 4 - Summary And Discussion Sessions

The step related to the summary and discussion was conducted in a session where the assessor tried to review, together with Tulipa, the guiding questions, the results of the instruments, and the experiences lived in the intervention sessions. Together, the client and the psychologist identified remarkable and challenging moments in the process, such as when Tulipa talked about her brother's death and recalled the situations she lived with him, as well as her discomfort during the application of some psychological tests and what could be associated to this feeling.

During the session, Tulipa shared the draft of the letter written by the psychologist. The text was a synthesis of the whole process, the results of the instruments, the referral, and the subsequent orientations. In the letter, the psychologist summarized 4 points discussed with Tulipa during the TA process: issues related to the client's overload and the possibility of not having to deal with everything on her own; the way Tulipa often gave up her desires in favor of others; reflections associated with the dynamics of a relationship, highlighting the character of exchange - giving and taking - inherent in any relationship; and the possibility that the client needs help to progressively deal with the painful emotions she experienced. Based on these aspects, the assessor suggested that Tulipa should remain in a psychotherapeutic process at the university's psychology service.

The psychologist agreed with the client how the letter delivery process would proceed, in addition to the information on the Evaluation Questionnaire. In this session, they agreed on the day the next stage would occur, namely, the Follow-up Session. Additionally, the assessor informed the client that, in the subsequent session, Tulipa would be introduced to the intern who would be responsible for conducting her psychotherapeutic process.

\section{Step 5 - Written Feedback}

As previously agreed, the completed letter and the Evaluation Assessment were available in a sealed envelope at the reception of the Psychology Service. Tulipa collected the envelope containing the documents, committing to returning the completed questionnaire at the next session.

\section{Stage 6 - Follow-Up Session}

The follow-up session took place 1 month and 18 days after the previous step. In this session, Tulipa described the feeling of overload related to her mother's illness process. In this regard, she stated that she desired to share her feelings and responsibilities with one of her sisters. The assessor stressed that the client's attitude in sharing the tasks was perhaps an indication of a possible change. Tulipa reflected and agreed, reporting that, in the past few days, she had thought about not necessarily having to solve everything on her own, although sharing was still a challenge to her.

The psychologist reinforced the importance of the client continuing her self-knowledge process, informing the main distinctions between the TA model and psychotherapy. In parallel, Tulipa mentioned several situations and difficulties that could be addressed in psychotherapy. Then, the instruments that had previously been administered in the screening were reapplied, namely the MIS, the SRQ-20, the RSES, and the Beck Scales. At the end of this step, the Psychology Service intern who was responsible for accompanying Tulipa in the psychotherapeutic process was called and introduced.

The results of the Evaluation Assessment showed that Tulipa was able to connect positively with the psychologist, thus establishing a satisfactory relationship. Furthermore, it was found that, during the process, the client felt welcomed and accepted, favoring the expansion of self-knowledge and the development of changes.

\section{Long-Term Monitoring}

Six months after the follow-up session, the intern responsible for accompanying Tulipa in psychotherapeutic care sent a letter to the assessor who developed the TA process. In the writing, the contributions that the TA model provided to Tulipa and the psychotherapy process were highlighted, reinforcing Tulipa's ability to understand the functioning of psychotherapy and the client's easy adherence to the process. Also, the intern pointed out the establishment of objective goals by Tulipa during psychotherapy.

\section{Discussion}

During the first visits, Tulipa presented some difficulty in talking about herself, sometimes limiting herself to narrating facts that touched her demands. It was possible to understand this characteristic since the client came into more intense contact with her questions and was able to describe her difficulty in expressing herself. In this process, it was up to the assessor to present an empathetic attitude and promote 
a welcoming environment, as discussed by Finn (2017). Also, Villemor-Amaral (2016) states that the assessor should listen and accept the client's complaint, helping him or her to elaborate the guiding questions, highlighting, especially in these first sessions, that the client should feel accepted and protected, favoring the establishment of a satisfactory bond with the assessor.

The process of forming the guiding questions is an essential element for the TA model (Aschieri, Saeger \& Durosini, 2015; Chudzik, 2015). The construction of the questions can be characterized as a complex and emotionally mobilizing process, which was identified, specifically for Tulipa, as a challenge given the importance of talking about herself and taking an active stance concerning what she wants to evaluate.

Finn (2017) points out that the strategies used in TA during the initial sessions make it possible to increase the motivation of clients to participate more openly and honestly in the subsequent stage, concerning the administration of psychological tests, which was perceived, in Tulipa, from the reactions to the tests used. The client openly expressed the reasons why she found the experience of responding to projective tests unpleasant, attributing her discomfort to the difficulty in identifying content in the stimuli. Also, the information obtained with the instruments allowed the client's responses to be identified as authentic while resulting in information consistent with Tulipa's demands and provided the development of therapeutic interventions.

Regarding the second step, unlike traditional psychodiagnosis where these instruments qualify as strategies for information collection (CFP, 2018), in $\mathrm{TA}$, the administration of the tests, as well as the data obtained from them, function as discussion elements. This resource aims to provide a reflective process that will potentially reflect changes in the client's problem solving mechanisms (Finn, 2017). The choice of BFP and Rorschach instruments, respectively a self-report and projective test, corroborates Finn's score (2017) regarding the potential related to the use of self-reports and projective instruments in evaluation processes, since, according to the author, different test models can provide a more complex collection of information around the same construct.

The development of the intervention sessions led Tulipa to an active process of self-observation. Understanding that she had difficulty in expressing emotions, Tulipa could rethink her role in the face of the demands brought about, which makes it possible to expand the possibilities of solving her problems. Thus, the discussion of the information obtained, associating it with the questions elaborated by Tulipa, can be identified as a process that facilitates the changes, since the client was able to recognize how her demands reflected her way of acting in certain situations. Furthermore, the client was able to exemplify the repetition of this functioning in other relationships, as well as the similarities of consequences associated with her behavior in similar contexts. Likewise, the other resources used (Zulliger and TAT tests, illustrative images, and recordings) allowed the client to visualize her difficulties and, from this confrontation, reflect on other possibilities.

In the stage referring to the summary and discussion session, information related to the 3 levels pointed out by Finn (2017) was discussed with Tulipa. Therefore, the client easily recognized Level 1 information, associated with resistance to the new. As for Level 2 information, regarding too much concern for people, there was a greater resistance from Tulipa; however, the client could present an example of similar experiences, subsequently agreeing with the information. The third level of information is presented in the literature (Finn, 2017) as content that is difficult to assimilate. In the case of Tulipa, the client showed high emotional mobilization when talking about her way of dealing with losses, since this content is associated with very negative feelings. According to Aschieri et al. (2015), during this step, the client should be encouraged to get involved, discuss, and exemplify the content covered with her experiences, thus being able to confirm or reject the information.

In the penultimate step, handing over and written feedback, the psychologist prepared a letter with a summary of the entire process, signaling the guiding questions, the results of the instruments, and the necessary referrals. According to Frackowiak, Fantini, and Aschieri (2015), a letter is a tool that helps to improve the effectiveness of the evaluation, and according to Vieira (2017), it is still a therapeutic tool that helps strengthen the psychologist/client relationship. Based on what was discussed in the session, the letter can be understood as a strategy that strengthened the relationship between Tulipa and the psychologist. Furthermore, the writing was configured as a possibility to improve the effectiveness of the assessment process, considering the importance of the client's access to the written record of important contents worked on during consultations. The last step, related to the follow-up session, was developed according to the recommendations of Finn (2017), occurring more than a month after the previous 
step. In this session, we sought to analyze the evolution of Tulipa and the benefits achieved by using TA.

From the results of the test-retest process performed using the instruments used in the screening, we found that Tulipa continued to present psychological distress and mild symptoms of anxiety and depression. Although the client did not show significant changes concerning psychological suffering, we assumed that the way she started to deal with suffering changed, perceiving it not as an end in itself or something with no possibility of change, but as something that can be changed. It is noteworthy that TA does not propose to promote significant changes in psychopathologies; but that the client transforms the way he or she deals with difficulties, intentionally seeking strategies to face them.

Such analysis can be perceived from the results obtained by Tulipa during the follow-up session, in addition to the results obtained from the Evaluation Assessment, which are consistent with an increase in self-knowledge provided by the TA process. The importance of strategies for result analysis that consider the social consequences related to the development of TA is also emphasized since when compared to the evaluation processes, this modality presents itself as a rupture of the traditional paradigms inherent to psychodiagnosis (Villemor -Amaral, 2016) from its transformative proposal towards expanding the evaluation process.

The scenario related to the study of Therapeutic Evaluation in Brazil is marked by the contemporaneity of the theme, considering the pioneering nature that characterizes the publication by Villemor-Amaral (2016) in the context of Brazilian scientific production. If, on the one hand, the originality of the model allows a wide range of research possibilities in the national context, on the other hand, it requires caution on the part of researchers, since its complexity is sometimes not apprehended in superficial contact with the topic. Regarding the conduct of the case explained in this study, it is important to stress the need for intense professional preparation of the psychologist and of the entire research team involved, especially regarding the planning and execution of the entire process.

Finally, it is necessary to reflect on possible limitations involved in conducting the case, emphasizing the excessive number of sessions developed in the intervention phase, which included 4 meetings. It may have been too long and exhausting for the client, making it necessary to think of an intervention session that addresses, in a less fragmented way, the demand considered central to the process. Finally, we emphasize the impossibility of generalizing the results when considering the objectives that guide a case study, aimed at deepening qualitative data. Thus, we support the continuity of studies aimed at broadening the understanding of the particularities and benefits achieved by TA in the Brazilian context.

\section{References}

Aschieri, F., \& Smith, J. D. (2012). The effectiveness of Therapeutic Assessment with an adult client: A single-case study using a time-series design. Journal of Personality Assessment, 94(1), 1-11. doi: 10.1080/00223891.2011.627964

Aschieri, F., Saeger, H., \& Durosini, I. (2015). L'évaluation thérapeutique et collaborative: Preuves empiriques. Pratiques Psychologiques, 21(1), 307-317. doi: 10.1016/j.prps.2015.09.005

Baptista, M. N. (2009). Inventário de Percepção de Suporte Familiar (IPSF). São Paulo: Vetor.

Chudzik, L. (2015). Évaluation thérapeutique et obligation de soins. Pratiques Psychologiques, 21(4), 331-343. doi: 10.1016/j.prps.2015.09.009

Cunha, J. A. (2001). Manual da versão em português das Escalas Beck. São Paulo: Casa do Psicólogo.

Durosini, I., Tarocchi, A., \& Aschieri, F. (2017). Therapeutic Assessment with a client with persistent complex bereavement disorder: A single-case timeseries design. Clinical Case Studies, 16(4), 295-312. doi: $10.1177 / 1534650117693942$

Exner, J. E. (1999). Manual de classificação do Rorschach para o sistema compreensivo. (Vol. 1) (A. C. Pacheco, Trad.) São Paulo: Casa do Psicólogo. (Original publicado em 1995).

Fantini, F. (2016). Family traditions, cultural values and the assessor's countertransference: Therapeutic Assessment of a young sicilian woman. Journal of Personality Assessment, 98(6), 576-584. doi: 10.1080/00223891.2016.1178128

Finn, S. E. (2015). Therapeutic Assessment with couples. Pratiques Psychologiques, 21(4), 345-373. doi: 10.1016/j.prps.2015.09.008

Finn, S. E. (2017). Pela perspectiva do cliente: Teoria e técnica da Avaliação Terapêutica (C. C. Bartalotti, Trad.). São Paulo: Hogrefe. (Original publicado em 2007).

Psico-USF, Bragança Paulista, v. 26, n. 3, p. 429-438, jul./set. 2021 
Frackowiak, M., Fantini, F., \& Aschieri, F. (2015). L'évaluation thérapeutique: Description de quatre modèles. Pratiques Psyhologiques, 21(4), 319-330. doi: 10.1016/j.prps.2015.09.005

Hinrichs, J. (2015). Inpatient Therapeutic Assessment with narcissistic personality disorder. Journal of Personality Assessment, 98(2), 111-123. doi: 10.1080/00223891.2015.1075997

Hutz, C. S., \& Zanon, C. (2011). Revisão da adaptação, validação e normatização da Escala de Autoestima de Rosenberg. Avaliação Psicológica, 10(1), 41-49. Recuperado de https://bit.ly/2JzJHFV

Murray, H. A. (2005). T.A.T.: Teste de Apercepção Temática. (3a ed.). São Paulo: Casa do Psicólogo.

Nunes, C. H. S. S., Hutz, C. S., \& Nunes, M. F. O. (2014). Bateria Fatorial de Personalidade - BFP: Manual técnico. São Paulo: Casa do Psicólogo.

Resolução CFP n. 9, de 25 de Abril de 2018. (2018). Estabelece diretrizes para a realização de Avaliação Psicológica no exercício profissional da psicóloga e do psicólogo, regulamenta o Sistema de Avaliação de Testes Psicológicos - SATEPSI e revoga as Resoluções $n^{\circ} 002 / 2003, n^{\circ} 006 / 2004$ e n ${ }^{\circ} 005 / 2012$ e Notas Técnicas n 01/2017 e 02/2017. Brasília. Recuperado de https://bit.ly/2JyBphv

Saeger, H., Bartak, A., Eder, E. E., \& Kamphuis, J. H. (2016). Memorable experiences in Therapeutic Assessment: Inviting the patient's perspective following a pretreatment randomized controlled trial.
Journal of Personality Assessment, 98(5), 472-479. doi: 10.1080/00223891.2015.1136314

Santos, L. O. B., Araújo, T. M., Pinho, P. S., \& Silva, A. C. C. (2011). Avaliação de um instrumento de mensuração de morbidade psíquica: Estudo de validação do Self-Reporting Questionnaire (SRQ20). Revista Baiana de Saúde Pública. 34(3), 344-560. doi: 10.22278/2318-2660.2010.

Scaduto, A. A., Cardoso, L. M., \& Heck, V. S. (2019). Modelos interventivo-terapêuticos em avaliação psicológica: Estado da arte no Brasil. Avaliação Psicológica, 18(1), 67-75. doi: 10.15689/ ap.2019.1801.16543.08

Tavares, M. (2003). Validade Clínica. Psico-USF, 8(2), 125-136. doi: 10.1590/S1413-82712003000200004

Vieira, P. G., Villemor-Amaral, A. E., \& Pianowski, G. (2017). Tradução, adaptação e evidências iniciais de validade da Magical Ideation Scale. Psicologia: Teoria e Pesquisa,32(4), 1-7.doi: 10.1590/0102.3772e324222

Villemor-Amaral, A. E. (2016). Perspectivas para a Avaliação Terapêutica no Brasil. Avaliação Psicológica, 15(2), 249-255. doi: 10.15689/ap.2016.1502.13

Villemor-Amaral, A. E., \& Resende, A. C. (2018). Novo modelo de avaliação psicológica no Brasil. Psicologia: Ciência e Profissão, 38(spe), 122-132. doi: 10.1590/1982-3703000208680

Recebido em: 29/05/2019

Reformulado em: 02/05/2020

Aprovado em: 17/08/2020 
About the authors:

Scarlett Borges Fernandes - Psychologist, PhD student at the Graduate Program in Psychology at the Universidade São Francisco. Campinas, São Paulo, Brazil.

Contact number: +55 (85) 99982-3068.

ORCID: https://orcid.org/0000-0001-6584-1060

E-mail:scarlettmoreira@hotmail.com

Rebeca de Moura Targino - Psychologist, Master's student at the Graduate Program in Psychology at the Universidade Federal do Ceará, Fortaleza, Ceará, Brazil.

Contact number: +55 (88) 99781-2180.

ORCID: http://orcid.org/0000-0002-1371-8260

E-mail: rebecatargino2@gmail.com

Fernanda da Fonseca Giasson - Psychologist, Master in Education from the Graduate Program in Education at the Universidade Federal do Ceará, Fortaleza, Ceará, Brazil.

Contact number: +55 (85) 99938-8589.

ORCID: https://orcid.org/0000-0003-4998-1762

E-mail: fergiasson@gmail.com

Lucila Moraes Cardoso - PhD in Psychology - Professor at the Universidade Estadual do Ceará, Humanities Center, Department of Psychology.

ORCID: http://orcid.org/0000-0002-8890-9352

E-mail:1ucila.cardoso@uece.br

\section{Contact:}

Av. Dr. Silas Munguba, 1700 - Campus do Itaperi

Fortaleza-CE, Brasil

CEP: 60741-000

Contact Number: (85) 3101-9987 